\title{
ENDOGENOUS AND EXOGENOUS CONTROL OF ECOSYSTEM FUNCTION: N CYCLING IN HEADWATER STREAMS
}

\author{
H. M. Valett,${ }^{1,7}$ S. A. Thomas, ${ }^{1,2}$ P. J. Mulholland,${ }^{3}$ J. R. Webster, ${ }^{1}$ C. N. Dahm, ${ }^{4}$ C. S. Fellows,${ }^{4,5}$ \\ C. L. Crenshaw, ${ }^{1,4}$ and C. G. Peterson ${ }^{6}$ \\ ${ }^{1}$ Department of Biological Sciences, Virginia Tech, Blacksburg, Virginia 24061 USA \\ ${ }^{2}$ Department of Biology, University of Nebraska, Lincoln, Nebraska 68588 USA \\ ${ }^{3}$ Environmental Sciences Division, Oak Ridge National Laboratory, Oak Ridge, Tennessee 37831 USA \\ ${ }^{4}$ Department of Biology, University of New Mexico, Albuquerque, New Mexico 87131 USA \\ ${ }^{5}$ Australian Rivers Institute and Griffith School of the Environment, Faculty of Environmental Sciences, Griffith University, \\ Nathan, Queensland, 4111, Australia \\ ${ }^{6}$ Department of Natural Sciences, Loyola University Chicago, Evanston, Illinois 60626 USA
}

\begin{abstract}
Allochthonous inputs act as resource subsidies to many ecosystems, where they exert strong influences on metabolism and material cycling. At the same time, metabolic theory proposes endogenous thermal control independent of resource supply. To address the relative importance of exogenous and endogenous influences, we quantified spatial and temporal variation in ecosystem metabolism and nitrogen $(\mathrm{N})$ uptake using seasonal releases of ${ }^{15} \mathrm{~N}$ as nitrate in six streams differing in riparian-stream interaction and metabolic character. Nitrate removal was quantified using a nutrient spiraling approach based on measurements of downstream decline in ${ }^{15} \mathrm{~N}$ flux. Respiration $(R)$ and gross primary production (GPP) were measured with whole-stream diel oxygen budgets. Uptake and metabolism metrics were addressed as $z$ scores relative to site means to assess temporal variation. In open-canopied streams, areal uptake $\left(U ; \mu \mathrm{g} \mathrm{N} \cdot \mathrm{m}^{-2} \cdot \mathrm{s}^{-1}\right)$ was closely related to GPP, metabolic rates increased with temperature, and $R$ was accurately predicted by metabolic scaling relationships. In forested streams, $N$ spiraling was not related to GPP; instead, uptake velocity $\left(v_{\mathrm{f}} ; \mathrm{mm} / \mathrm{s}\right)$ was closely related to $R$. In contrast to open-canopied streams, $\mathrm{N}$ uptake and metabolic activity were negatively correlated to temperature and poorly described by scaling laws. We contend that streams differ along a gradient of exogenous and endogenous control that relates to the relative influences of resource subsidies and in-stream energetics as determinants of seasonal patterns of metabolism and $\mathrm{N}$ cycling. Our research suggests that temporal variation in the propagation of ecological influence between adjacent systems generates phases when ecosystems are alternatively characterized as endogenously and exogenously controlled.
\end{abstract}

Key words: endogenous; exogenous; metabolic theory; nitrogen uptake; primary production; respiration; spatial subsidies; streams; temporal variation; uptake length; uptake velocity.

\section{INTRODUCTION}

Endogenous and exogenous drivers organize the structure and function of ecological systems at multiple scales. Concepts like source-sink relationships (Pulliam 1988) and metapopulation dynamics (Hanski 1998) link the endogenous processes of birth and death to dispersal among habitats and subpopulations. More recently, resolving the roles of internal and external influences has emerged in the context of food web ecology. Maron et al. (2006) emphasized that food web studies over the past several decades have coalesced around two conceptual foci including, (1) the trophic cascade concepts emphasizing endogenous drivers (Pace et al. 1999) and (2) spatial subsidies to food webs recognizing

Manuscript received 20 June 2007; revised 13 February 2008; accepted 7 March 2008; final version received 2 April 2008. Corresponding Editor: J. B. Yavitt.

${ }^{7}$ E-mail: mvalett@vt.edu the flow of organisms, materials, and energy among food webs (Polis et al. 2004). While emphasis on spatial subsidies to populations and communities may be more recent, ecosystem ecologists have long recognized the importance of allochthonous resources to central processes like energy flow and material cycling (Odum 1956, Fisher and Likens 1973, Cole et al. 2006).

The influence of resource subsidies depends upon their relative magnitude and quality (e.g., elemental composition). At the ecosystem level, subsidies of interest include inorganic nutrient inputs that stimulate primary production and support grazer food webs (Peterson et al. 1986, DeAngelis and Mulholland 2004) and detrital fluxes that sustain decomposer pathways (Odum and de la Cruz 1963, Cole et al. 2006). Linked systems need not be spatially contiguous, as illustrated by the importance of marine-derived nitrogen $(\mathrm{N})$ for inland vegetation (Nagasaka et al. 2006) and terrestrial food webs (Helfield and Naiman 2006). Once supplied, imported nutrients influence resource elemental composition (i.e., ecological 
TABLE 1. Site characteristics for the six study streams.

\begin{tabular}{|c|c|c|c|c|}
\hline \multirow[b]{2}{*}{ Characteristic } & \multicolumn{2}{|c|}{$\begin{array}{c}\text { Coweeta Hydrologic Lab, } \\
\text { North Carolina, USA (CWT) }\end{array}$} & \multicolumn{2}{|c|}{$\begin{array}{c}\text { Oak Ridge National Laboratory, } \\
\text { Tennessee, USA (ORNL) }\end{array}$} \\
\hline & $\begin{array}{l}\text { Hugh White Creek } \\
\text { (HWC) }\end{array}$ & $\begin{array}{l}\text { Snake Den Branch } \\
\text { (SD) }\end{array}$ & $\begin{array}{l}\text { West Fork Walker } \\
\text { Branch (WFWB) }\end{array}$ & $\begin{array}{l}\text { East Fork Walker } \\
\text { Branch (EFWB) }\end{array}$ \\
\hline Catchment setting & $\begin{array}{l}\text { mesic hardwood, } \\
\text { evergreen understory }\end{array}$ & $\begin{array}{l}\text { mesic hardwood, } \\
\text { evergreen understory }\end{array}$ & $\begin{array}{l}\text { hardwood, } \\
\text { sparse understory }\end{array}$ & $\begin{array}{l}\text { hardwood, } \\
\text { sparse understory }\end{array}$ \\
\hline Canopy cover & highest & highest & moderate & moderate \\
\hline Reach elevation (m) & 820 & 865 & 275 & 290 \\
\hline Catchment area (ha) & 20 & 28 & 38 & 59 \\
\hline Geology & granite & granite & dolomite & dolomite \\
\hline Hydrology & perennial runoff & perennial runoff & mesic groundwater & mesic groundwater \\
\hline Stream gradient $(\%)$ & 23 & 22 & 4 & 3 \\
\hline Annual precipitation $(\mathrm{cm})$ & 200 & 200 & 140 & 140 \\
\hline
\end{tabular}

Note: Additional information on the streams was given by Valett et al. (1996) and Mulholland et al. (1997).

stoichiometry; Sterner and Elser 2002) and interact with biotic demand to dictate rates of material cycling.

Other studies emphasize more internal organization of ecosystem dynamics. Based on metabolic theory, Brown et al. (2004) argued that variation in organismal metabolism results in metabolic scaling relationships that can explain emergent features at all levels of ecological organization. The theory extends the relationships between body size, temperature, and respiration (Gillooly et al. 2001) to propose metabolic constraints at population and ecosystem levels (Enquist et al. 1998). Enquist et al. (2003) suggested that ecosystem metabolism (i.e., respiration) and temperature can be linked mathematically by an Arrhenius plot with a predictable slope, and proposed that the relationship is independent of standing stock.

Metabolic and subsidy theories appear diametrically opposed, but we argue that they are complementary and that reconciling the apparent contradiction lies in examining the mechanisms by which subsidies link adjacent ecosystems and how their importance varies with time. In this paper, we address the importance of relationships between metabolism and nutrient cycling in open ecosystems subject to spatial and temporal variation in endogenous and exogenous organizers.

These themes are addressed in headwater streams of forested or open-canopied reaches. In forested reaches, autumnal inputs of leaf litter act as punctuated resource subsidies, while seasonal variation in heat energy influences biological processes in both stream types.

As part of the Nitrate Processing And Retention in Streams (NPARS) project (Thomas et al. 2001), we used the nutrient spiraling concept (Webster and Patten 1979, Newbold et al. 1981) to describe nutrient cycling in streams. A spiral length $(S)$ is the sum of the uptake $\left(S_{\mathrm{W}}\right)$ and turnover $\left(S_{\mathrm{B}}\right)$ lengths (suggesting water and benthic associations, respectively). $S_{\mathrm{W}}$ is defined as the average distance traveled by a nutrient in inorganic form before removal from solution while $S_{\mathrm{B}}$ is the distance traveled in organic form before mineralization. Combined with information on stream hydrology and nutrient concentration, the spiraling framework yields metrics that describe ecosystem-scale biogeochemical activity. Diel oxygen budgets were used to derive measures of whole-stream metabolism. We selected six streams that varied in the extent of allochthonous inputs, thermal regime, and metabolic rates. Additions of heavy $\mathrm{N}$ isotopes as nitrate (i.e., ${ }^{15} \mathrm{NO}_{3}{ }^{-}$) were used to quantify nutrient spiraling while we simultaneously measured whole-system metabolism. By monitoring critical biomass compartments and seasonal variation in resources and temperature, we investigated how exogenous and endogenous drivers organize biogeochemical and metabolic relationships.

\section{STUdy Sites}

Pairs of study streams at three study sites (Table 1) were chosen to provide variation in influence of riparian vegetation and thermal conditions. Within each stream, single study reaches of 50-150 m length were used for a series of nutrient release experiments designed to assess spatial and temporal variation in $\mathrm{NO}_{3}-\mathrm{N}$ uptake.

Rio Calaveras (RC) and Gallina Creek (GC) are streams in north-central New Mexico (NCNM), USA, and are open-canopied systems that flow through meadows or areas of relatively sparse riparian cover (Fellows et al. 2006). The streams are well lit and support productive periphyton communities that are heavily cropped by dense populations of benthic invertebrate grazers (Peterson et al. 2001).

The East (EFWB) and West (WFWB) Fork of Walker Branch are first-order streams on the grounds of the U.S. Department of Energy's Oak Ridge National Laboratory (ORNL), Tennessee, USA. Relatively dense canopies of second-growth deciduous forest shade both streams. During most of the year, periphyton standing crop is low, but a brief bloom typically occurs in early spring before closing of the riparian canopy (Mulholland et al. 2006).

Hugh White Creek (HWC) and Snake Den Branch (SD) are second-order streams located at the Coweeta Hydrologic Laboratory (CWT), North Carolina, USA (see Plate 1). An extensive perennial understory of rhododendron beneath a deciduous forest canopy results 
TABLE 1. Extended.

\begin{tabular}{ll}
\hline \hline \multicolumn{2}{c}{ North Central } \\
\multicolumn{1}{c}{ New Mexico, USA (NCNM) } \\
\hline \multicolumn{1}{c}{ Gallina Creek (GC) } & \multicolumn{1}{c}{ Rio Calaveras } \\
(RC)
\end{tabular}

in very low light levels during all seasons (Webster et al. 1992).

\section{Methods}

Overview of experimental design.-Solute release experiments were used to characterize $\mathrm{NO}_{3}-\mathrm{N}$ transport and uptake using additions of ${ }^{15} \mathrm{NO}_{3}-\mathrm{N}$ and a hydrologic tracer. A single release was carried out at each of six streams during each season (Appendix A) to address spatial and temporal variation in $\mathrm{NO}_{3}-\mathrm{N}$ spiraling. Spring releases in NCNM streams were not possible due to snowmelt-enhanced discharge and $\mathrm{NO}_{3}-\mathrm{N}$ concentrations (i.e., $>150 \mu \mathrm{g} / \mathrm{L}$ ). During each release, we quantified standing stocks of dominant benthic compartments pertinent to stream sites, measured ecosystem metabolism, and monitored select physical-chemical features.

Solute release experiments. - We conducted 12-h continuous additions of $99 \%{ }^{15} \mathrm{~N}$-enriched $\mathrm{K}^{15} \mathrm{NO}_{3}$ along with chloride $\left(\mathrm{Cl}^{-}\right.$, from $\left.\mathrm{NaCl}\right)$ as a hydrologically conservative tracer. The $\mathrm{K}^{15} \mathrm{NO}_{3}$ additions were designed to produce a 40 -fold increase in the ${ }^{15} \mathrm{~N}:{ }^{14} \mathrm{~N}$ ratio of stream water $\mathrm{NO}_{3}-\mathrm{N}$, an enrichment level that elevated $\mathrm{NO}_{3}-\mathrm{N}$ concentration by $\sim 15 \%$. After $\sim 12$ hours, we collected replicate water samples (four to seven stations downstream from the ${ }^{15} \mathrm{~N}$ release in each stream), which were corrected for background and dilution influences (following standard protocols; Stream Solute Workshop 1990) to evaluate N cycling. Processing of ${ }^{15} \mathrm{NO}_{3}-\mathrm{N}$ samples followed a modified form of the reduction-diffusion method (Sigman et al. 1997). Samples were sent to the University of Waterloo Environmental Isotope Laboratory for analysis of ${ }^{15} \mathrm{~N}:{ }^{14} \mathrm{~N}$ ratios $( \pm 0.3 \%$ ) by mass spectrometry. Solute monitoring included chloride $\left(\mathrm{Cl}^{-}\right.$, as a hydrologic tracer), $\mathrm{NO}_{3}-\mathrm{N}$, and soluble reactive phosphorus (SRP) following standard methods (Table 2). Samples were filtered in the field or returned to the laboratory and filtered (Whatman GFF glass fiber filters [Whatman International, Kent, UK]; pore size $=0.7 \mu \mathrm{m}$ ) within two hours of collection.

Nutrient spiraling metrics. - Longitudinal uptake rate $\left(k_{\mathrm{L}} ; \mathrm{m}^{-1}\right)$ was derived as the slope of the line relating $\ln \left({ }^{15} \mathrm{~N}\right.$ flux) and distance downstream (m), and its inverse equals the gross $\mathrm{NO}_{3}-\mathrm{N}$ uptake length $\left(S_{\mathrm{W}} ; \mathrm{m}\right)$. The uptake velocity, $v_{\mathrm{f}}(\mathrm{mm} / \mathrm{s})$ normalizes $S_{\mathrm{W}}$ to hydrologic influences:

$$
v_{\mathrm{f}}=\frac{u d}{S_{\mathrm{W}}}
$$

where $u$ is stream velocity $(\mathrm{mm} / \mathrm{s})$ and $d$ is mean stream depth $(\mathrm{m})$. The uptake velocity is combined with background $\mathrm{NO}_{3}-\mathrm{N}$ to quantify the areal uptake rate $\left(U ; \mu \mathrm{g} \mathrm{N} \cdot \mathrm{m}^{-2} \cdot \mathrm{s}^{-1}\right)$ :

$$
U=v_{\mathrm{f}}\left[\mathrm{NO}_{3}-\mathrm{N}\right]
$$

where $\left[\mathrm{NO}_{3}-\mathrm{N}\right]$ is ambient background $\mathrm{NO}_{3}-\mathrm{N}$ concentration $(\mu \mathrm{g} / \mathrm{L})$.

Whole-system metabolism.-Reach-scale measurements of stream metabolism were made using a two-

\begin{tabular}{|c|c|c|c|}
\hline Compartment/variable & Method/instrument & Sample size $(n)$ & Reference \\
\hline \multicolumn{4}{|l|}{ Stream water chemistry } \\
\hline Chloride $\left(\mathrm{Cl}^{-}\right)$ & $\begin{array}{l}\text { ion chromatography, Dionex DX 500, } \\
\text { Dionex, Sunnyvale, California, USA }\end{array}$ & $3 /$ transect & APHA (2005) \\
\hline Nitrate-nitrogen $\left(\mathrm{NO}_{3}-\mathrm{N}\right)$ & $\begin{array}{l}\text { automated Cu-Cd reduction, azo dye } \\
\text { colorimetry, Technicon AAII, } \\
\text { Technicon, Emeryville, California, } \\
\text { USA }\end{array}$ & $3 /$ transect & APHA (2005) \\
\hline $\begin{array}{l}\text { Soluble reactive phosphorus } \\
\text { (SRP) }\end{array}$ & $\begin{array}{l}\text { colorimetry with ascorbic acid- } \\
\text { molybdate }\end{array}$ & $3 /$ transect & APHA (2005) \\
\hline \multicolumn{4}{|l|}{ Stream hydrology/morphometry } \\
\hline Discharge & dilution gauging & $1 /$ release & Gordon et al. (1992) \\
\hline Velocity & discharge and cross-sectional area & $1 /$ release & Stream Solute Workshop (1990) \\
\hline Depth and width & field measurements & $200 /$ release & Stream Solute Workshop (1990) \\
\hline \multicolumn{4}{|l|}{ Stream sediment } \\
\hline $\mathrm{CPOM}(>1 \mathrm{~mm})$ & cylindrical pot sampler & $3-5 /$ transect & Webster et al. (2003) \\
\hline FPOM & cylindrical pot sampler & $3-5 /$ transect & Webster et al. (2003) \\
\hline Epilithic chl $a$ & scraping and pigment analysis & $3-5$ rocks & Steinman et al. (2006) \\
\hline Epilithic OM & ash-free dry mass & $3-5$ rocks & Steinman et al. (2006) \\
\hline
\end{tabular}

TABLE 2. Field and laboratory methods for assessing ecosystem structure of study streams.

Note: Abbreviations are: CPOM, coarse particulate organic matter; FPOM, fine particulate organic matter; OM, organic matter. 
station oxygen technique (Marzolf et al. 1994). Dissolved oxygen (DO) and water temperature were measured using automated sondes (YSI Model 2607, YSI, Yellow Springs, Wisconsin, USA; or Hydrolab Model 4A, Hydrolab, Hach Environmental, Loveland, Colorado, USA) at intervals of 5-15 min over $24 \mathrm{~h}$. Exchange with the atmosphere was calculated from longitudinal declines of propane or sulfur hexafluoride $\left(\mathrm{SF}_{6}\right.$; Marzolf et al. 1994). Respiration (R) rate was determined from changes in DO flux during night. Daytime $R$ was determined by extrapolating linearly from an hour before dawn to one hour post-dusk. Rates of gross primary production (GPP) were determined as the summed difference between the observed net rate of oxygen change and extrapolated daytime respiration rate. Insolation was measured as flux density $\left(\mathrm{mol} \cdot \mathrm{m}^{-2} \cdot \mathrm{d}^{-1}\right)$ for photosynthetically active radiation (PAR) monitored at a single location within each study reach, using a quantum sensor (LICOR 190SA, LICOR, Lincoln, Nebraska, USA). Net ecosystem production (NEP) was determined as GPP $-R$.

Stream ecosystem structure.-We documented sediment organic matter (OM), epilithic chlorophyll $a$ (chl), and measurements of stream flow along each of the study reaches (Table 2). Cylindrical samplers were placed on the stream bed to collect coarse particulate $\mathrm{OM}(\mathrm{CPOM} ;>1 \mathrm{~mm})$ and fine particulate OM (FPOM; $<1 \mathrm{~mm}$ ). Measures of CPOM and FPOM standing stocks in NCNM streams were lost due to technical error. Representative rocks were collected and processed for biofilm $\mathrm{OM}$ and chl. Reach-scale averages were determined using standings stocks weighted for percentage of habitat occupied by bedrock, riffles, and pools. Stream discharge and velocity were determined by dilution gauging (Gordon et al. 1992; Table 2).

Statistical assessment. - Variation in physical-chemical conditions among sites was assessed using one-way analysis of variance (ANOVA) with site (CWT, ORNL, NCNM) as the main effect (Sokal and Rohlf 1981). Based on similarity in physical-chemical features, experiments from CWT and ORNL were combined to address differences between forested and open-canopied sites using $t$ tests on grand means ( $n=6$ and $n=22$ for open-canopied and forested types, respectively). Temporal change in ecosystem structure and function was assessed using one-way ANOVA with season as the main effect. Given the relatively small data set available to address temporal trends $(n=4$ seasons; $4-6$ observations per season), use of repeated-measures or time-series approaches were considered inappropriate, and we employed one-way ANOVA of $z$ scores (Eq. 3) to assess temporal influences:

$$
z \text { score }=\frac{\left(y_{\mathrm{i}}-\bar{y}\right)}{\mathrm{SD}}
$$

where $y_{\mathrm{i}}, \bar{y}$, and SD are individual observations, mean values, and standard deviations for a given stream. This yields a mean of zero and an SD of one for each stream, and effectively normalizes measures for spatial variation among streams. For all significant ANOVAs, differences among factor levels (site or season) were assessed using Tukey's multiple comparison test with $\alpha=0.05$. Correlation analysis was used to investigate relationships between measures of ecosystem structure and function. To address the influence of outliers and deviation from normality, we calculated both parametric (Pearson product-moment, $r_{\mathrm{P}}$ ) and nonparametric (Spearman rank, $r_{\mathrm{S}}$ ) correlation coefficients. Scaling relationships between ecosystem metabolism and stream temperature were addressed using an Arrhenius plot (Eq. 4) following Enquist et al. (2003):

$$
\ln (R)=\frac{-E}{1000 k}\left(\frac{1000}{T}\right)+\ln \left[\left(b_{\mathrm{o}}\right)(C)\right]
$$

where $R$ is areal respiration, $E$ is activation energy (0.6 $\left.\mathrm{eV} ; 1 \mathrm{eV}=1.60218 \times 10^{-19} \mathrm{~J}\right), k$ is the Boltzmann constant $8.62 \times 10^{-5} \mathrm{eV} \mathrm{K}^{-1}, T$ is stream temperature in degrees Kelvin, and $b_{\mathrm{o}}$ and $C$ are normalization constants. Accordingly, Eq. 4 should yield a slope of $-0.6 \mathrm{eV}$ when $\ln (R)$ is plotted against $1 / k T$ (Enquist et al. 2003). Scaling relationships were also analyzed for respiration normalized to organic matter standing stocks. We addressed how well metabolic theory predicted stream metabolism with linear regression using these whole-stream respiration measures and associated temperatures for the combined data set and for forested and open sites independently. For all measures, relative variance was expressed as the coefficient of variation (CV) where CV is (mean/ standard deviation) $\times 100 \%$.

\section{RESULTS}

Based on average annual values (Appendix B), streams in CWT and ORNL were considered structurally similar to each other and significantly different from NCNM streams. In general, CWT and ORNL streams had similar hydrologic features (velocity, depth, width), temperature, light availability, and stream water chemistry, while they differed from NCNM in most of these same variables (Appendix B). Ordination of seasonal measures of nine habitat variables used to predict features of stream metabolism and nutrient cycling explained $79 \%$ of the variance using three multivariate axes (Appendix C). Open-canopied streams were clearly separated from forested streams along the first axis where scores were correlated to photosynthetically active radiation (PAR; -0.45$), \mathrm{NO}_{3}-\mathrm{N}(-0.34)$, and soluble reactive phosphorus (SRP; -0.45 ). Further, seasonal variation in $\mathrm{N}$ spiraling metrics (Appendix $\mathrm{D}$ ) and leaf litter standing stocks (Appendix E) resulted in little statistical separation between CWT and ORNL. Accordingly, we retained seasonal distinctions for individual streams but combined measures from CWT and ORNL as forested sites and contrasted them with those from the open-canopied streams of NCNM. 

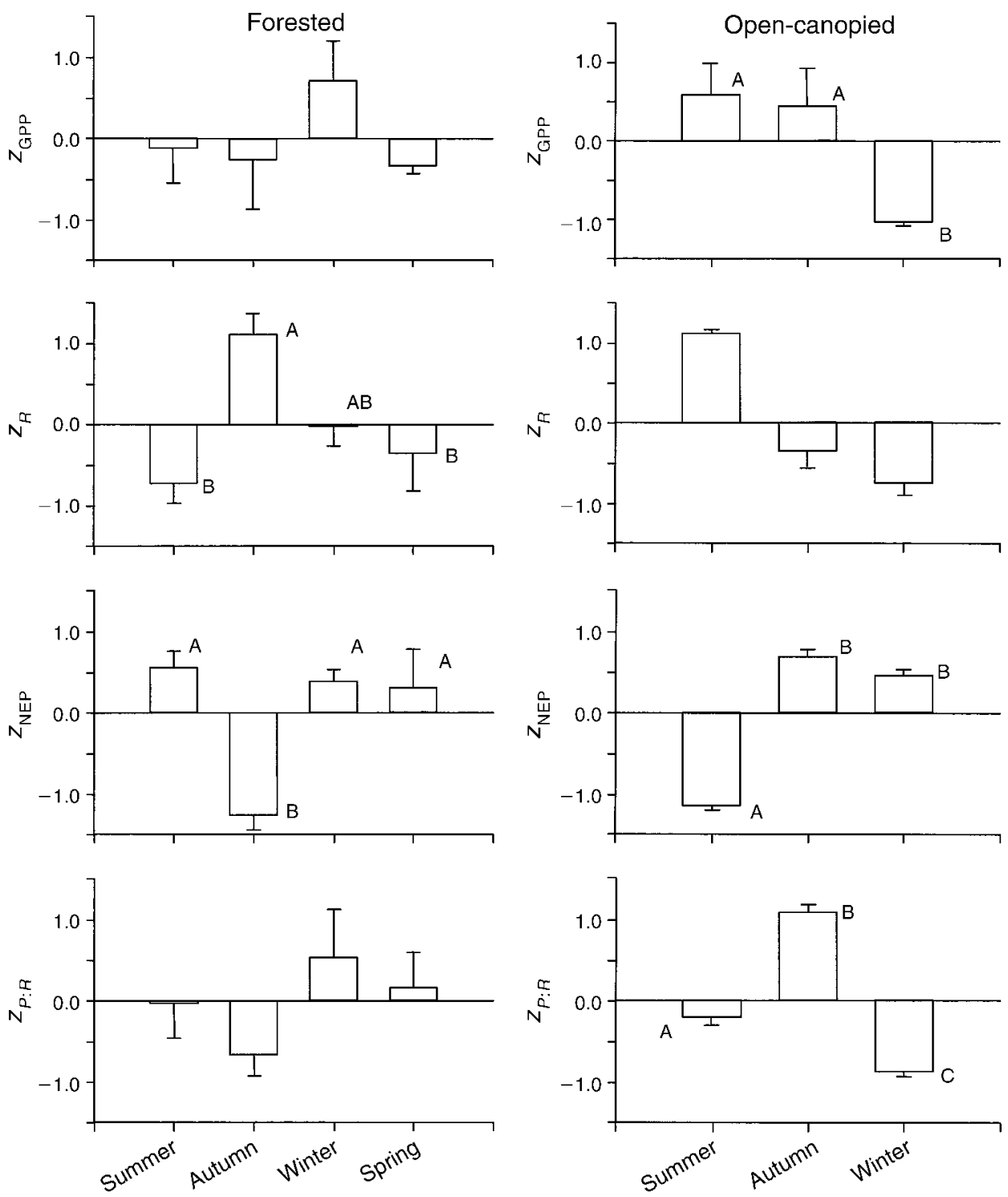

FIG. 1. Seasonal variation in ecosystem metabolism in forested and open-canopied streams. Data are $z$ scores as means $\pm \mathrm{SE}$ for gross primary production (GPP), respiration $(R)$, net ecosystem production (NEP), and $P: R(\mathrm{GPP}: R)$ ratio. Bars within a panel that are significantly different $(P<0.05$ from Tukey's hsd after one-way ANOVA) have different uppercase letters.

Forested and open-canopied streams: spatial and temporal variation.-In the forested streams, water temperature was significantly colder $(z$ score of temperature; $P<0.0001)$ during autumn and winter, and insolation was significantly lower $(z$ score of PAR; $P=$ 0.0003 ) during spring and summer (Appendix F) compared to other seasons. With the exception of CPOM, detrital standing stocks within the forested streams did not vary seasonally (Appendix G). Standing stocks of leaf litter (i.e., CPOM), however, were greater $(P<0.0001)$ in autumn than during other seasons. Mean $( \pm$ SE) standing stock of leaf litter in autumn was $181.4 \pm 20.2 \mathrm{~g} \mathrm{AFDM} / \mathrm{m}^{2}$ (ash-free dry mass) while averages during the other seasons varied from $9.8-27.7 \mathrm{~g}$ $\operatorname{AFDM} / \mathrm{m}^{2}$ (Appendix G).
Water temperature differed significantly across all seasons in our open-canopied streams $(P=0.002)$ while photon flux density $\left(11.1-30.1 \mathrm{~mol} \cdot \mathrm{m}^{-2} \cdot \mathrm{d}^{-1}\right.$; Appendix F) was high throughout the year. Mean $\mathrm{NO}_{3}-\mathrm{N}$ concentration in open-canopied streams $(66 \pm 27$ $\mu \mathrm{g} / \mathrm{L})$ was greater $(P=0.009 ; t$ test of grand means $)$ than in the forested streams $(15 \pm 4 \mu \mathrm{g} / \mathrm{L})$. Opencanopied streams contained more epilithic biomass than forested streams $\left(6.3 \pm 2.2\right.$ vs. $2.8 \pm 0.5 \mathrm{~g} / \mathrm{m}^{2} ; P=0.035$; Appendix $\mathrm{H})$, but chlorophyll standing crops were similar $(P=0.816$; Appendix $\mathrm{H})$. Values are expressed as mean $\pm \mathrm{SE}$.

Metabolic rates changed with season in both forested and open-canopied systems (Fig. 1), but responses differed with stream type. In forested streams gross 

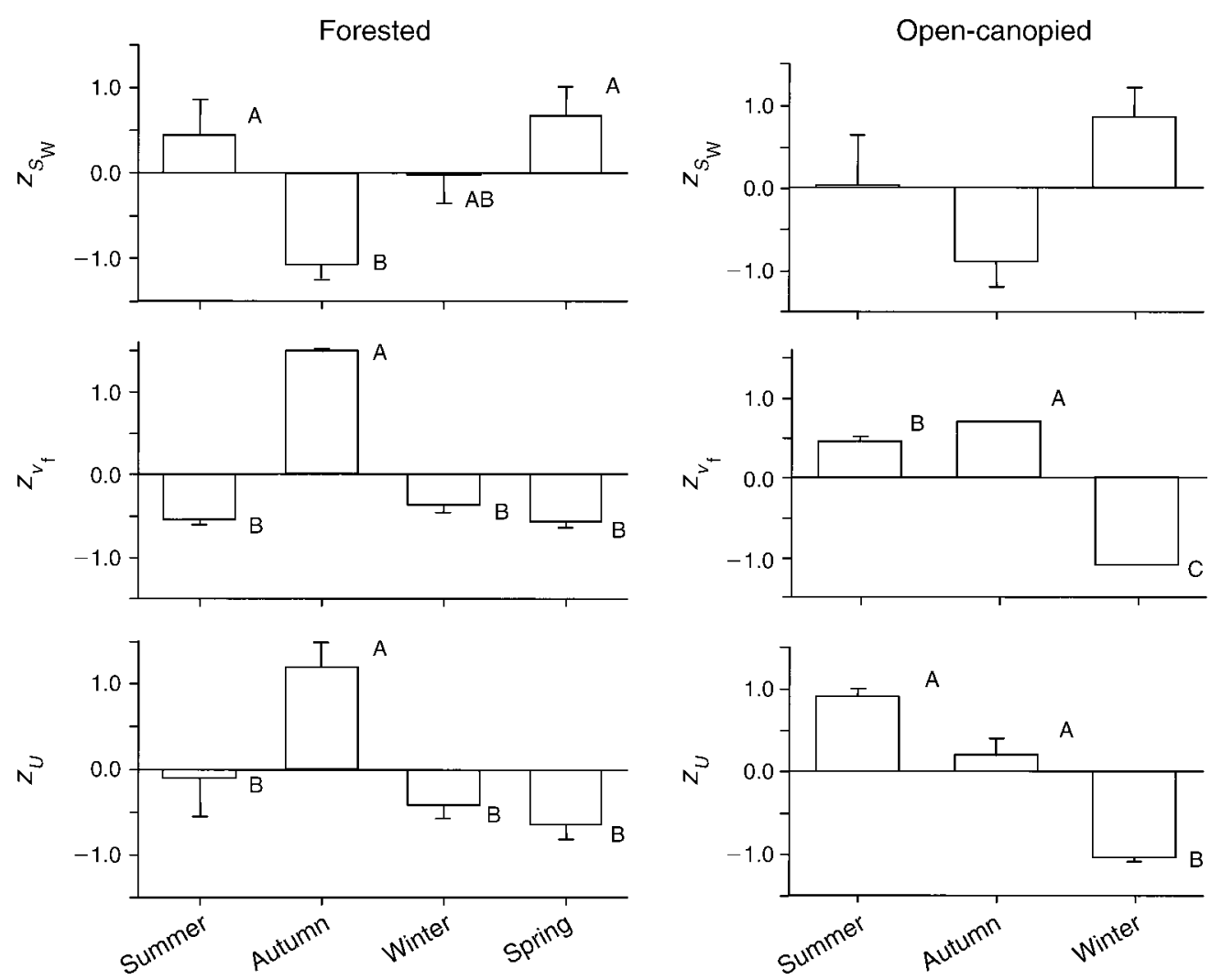

FIG. 2. Seasonal variation in nitrate uptake in forested and open-canopied streams. Data are $z$ scores presented as means \pm SE for uptake length $\left(S_{\mathrm{W}}\right)$, uptake velocity $\left(v_{\mathrm{f}}\right)$, and areal uptake $(U)$. Bars within a panel that are significantly different $(P<0.05$ from Tukey's hsd after one-way ANOVA) have different uppercase letters.

primary production (GPP) was low and not significantly different among seasons $(P=0.18$; Fig. 1; Appendix I). Respiration rates $(R)$, however, were highest in autumn and declined significantly $(P=0.006)$ through winter, spring, and summer (Fig. 1). Greatest $P: R$ ratio (GPP: $R$ ) occurred in autumn but was only 0.17 (Appendix I).

Rates for GPP in open-canopied streams $(0.32 \pm 0.10$ $\left.\mathrm{g} \mathrm{O}_{2} \cdot \mathrm{m}^{-2} \cdot \mathrm{d}^{-1}\right)$ were higher than those in forested sites $\left(0.20 \pm 0.10 \mathrm{~g} \mathrm{O}_{2} \cdot \mathrm{m}^{-2} \cdot \mathrm{d}^{-1}\right)$, but grand means did not differ significantly between stream types (mean $\pm \mathrm{SE} ; P$ $=0.34)$. In open-canopied streams, greatest GPP $(P=$ $0.02)$ and $R(P=0.005)$ occurred in summer (Fig. 1), generating a maximal $P: R$ of 0.37 (Appendix I).

Seasonal patterns of $\mathrm{N}$ uptake differed between stream types (Fig. 2). In forested streams, average nutrient uptake length $\left(S_{\mathrm{W}}\right)$ varied from $16-752 \mathrm{~m}$ across seasons (Appendix $\mathrm{J}$ ) and was shortest (Fig. 2; $P$ $=0.02)$ in autumn. Maxima for $v_{\mathrm{f}}(0.09 \mathrm{~mm} / \mathrm{s})$ and $U$ $\left(0.62 \mu \mathrm{g} \mathrm{N} \cdot \mathrm{m}^{-2} \cdot \mathrm{d}^{-1}\right)$ occurred in autumn when values were four to seven times greater than during other seasons $(P=0.004$ and 0.018 , respectively). In opencanopied systems, $S_{\mathrm{W}}$ was longer $(>1 \mathrm{~km}$ in winter and spring), and means did not differ significantly among seasons $(P>0.14$; Fig. 2 ; Appendix $\mathrm{J})$. Within these streams, $v_{\mathrm{f}}(P=0.0001)$ and $U(P=0.003)$ varied seasonally (Fig. 2); $v_{\mathrm{f}}$ was maximal $(0.03 \mathrm{mms} / \mathrm{s})$ during autumn while $U$ was greatest $\left(0.32 \mu \mathrm{g} \mathrm{N} \cdot \mathrm{m}^{-2} \cdot \mathrm{d}^{-1}\right)$ in summer.

Seasonal variation: coupling temporal change in structure and function.-In forested streams, temporal variation in $R$ was related to leaf litter standing crop ( $r_{\mathrm{P}}$ $=0.67, P=0.0005$ for $z$ scores; data not shown), and seasonal changes in $v_{\mathrm{f}}$ and $U$ were tied to $R$ (Fig. 3), with greater uptake associated with enhanced $R$. Spiraling metrics for $\mathrm{N}$ uptake were not related to GPP in forested streams.

While respiration and $\mathrm{N}$ uptake increased with increasing leaf litter stocks in forested streams, they declined with increasing stream temperature (Fig. 4). Respiration, $v_{\mathrm{f}}$, and $U$ were negatively correlated with water temperature both as untransformed data and as $z$ scores (Fig. 4). Ecosystem $R$ in forested streams was related to stream temperature in a manner opposite that predicted by metabolic scaling laws (Eq. $4 ; r^{2}=0.47, n=$ 16, $P=0.0035)$. The slope relating metabolism and temperature $(0.63 \pm 0.18 \mathrm{eV}$; slope $\pm \mathrm{SE})$ was nearly equal in magnitude but had a sign opposite to the predicted value (i.e., $-0.64 \mathrm{eV}$ ). Following removal of autumnal $R$, the relationship was no longer significant $\left(r^{2}=0.056, n=12, P=0.45\right)$. Scaling regressions for respiration normalized to organic matter standing stocks were not significant $(P>0.05)$. Accordingly, respiration 

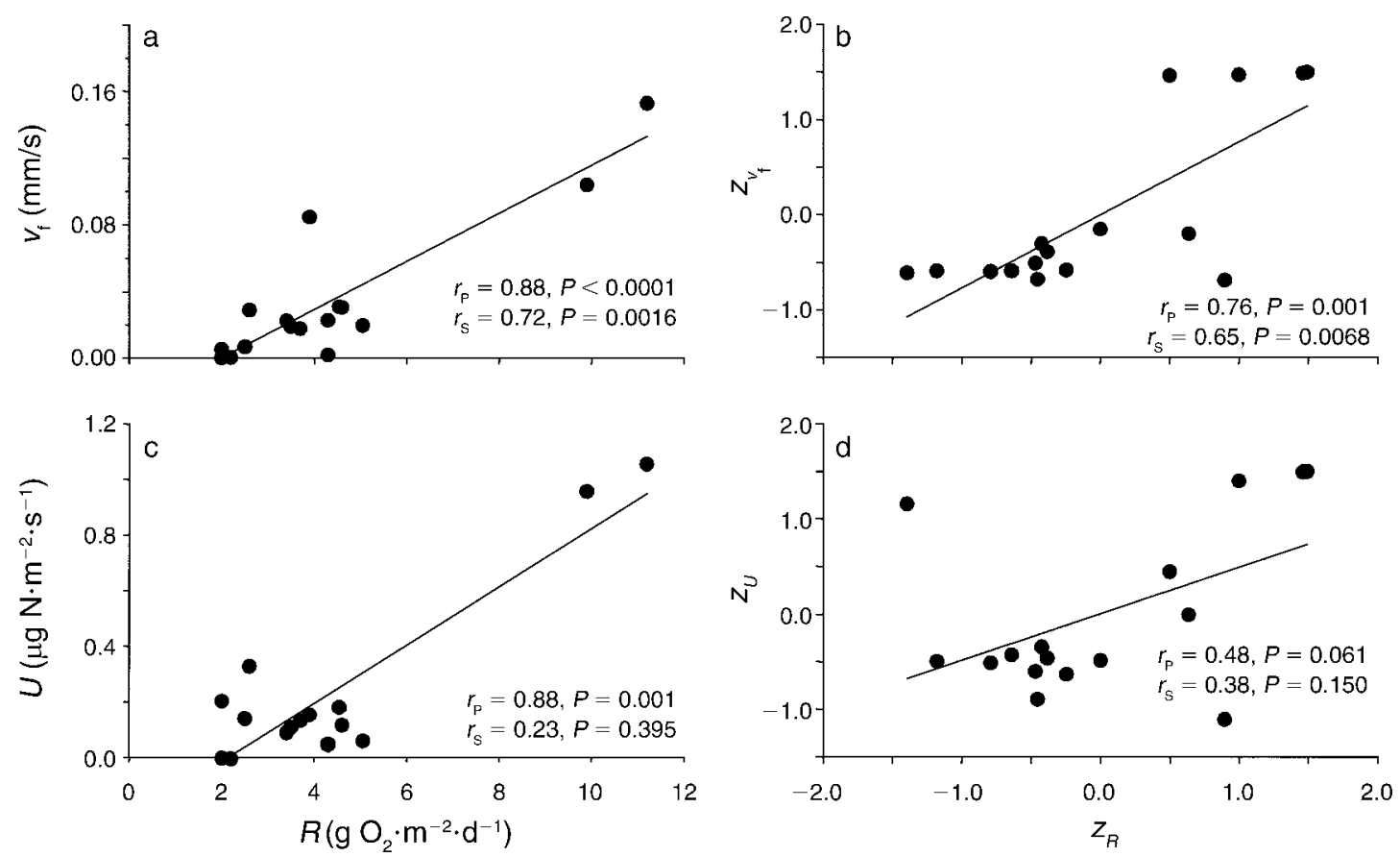

FIG. 3. Respiration $(R)$ vs. uptake velocity $\left(v_{\mathrm{f}}\right)$ or areal uptake $(U)$ for $(\mathrm{a}, \mathrm{c})$ untransformed data and $(\mathrm{b}, \mathrm{d}) z$ scores during solute releases in forested streams $\left(n=16\right.$ solute injections). Both parametric (Pearson product-moment, $\left.r_{\mathrm{P}}\right)$ and nonparametric (Spearman rank, $r_{\mathrm{S}}$ ) correlation coefficients and associated $P$ values are given.

normalized to leaf litter standing stock did not scale with temperature using all data from forested streams $\left(r^{2}=\right.$ $0.19, P=0.09)$ nor when autumnal data were excluded $\left(r^{2}=0.04, P=0.52\right)$.

In open-canopied streams, GPP was a strong predictor of $U$ (Fig. 5) and was positively related to $R(r=0.81$, $n=6, P=0.05$; data not shown). Accordingly, $U$ was also positively related to $R$ (Fig. 5). The relationships between $U$ and metabolic rates were significant both with untransformed variables and with $z$ scores calculated for $U$, GPP, and $R$. Uptake velocity was not significantly related to any measure of ecosystem metabolism (data not shown).

In open-canopied streams, rates of $\mathrm{N}$ uptake, ecosystem $R$, and GPP increased with temperature (Fig. 6), a pattern opposite that in forested streams (Fig. 4). As $z$ scores, GPP (Fig. 6a) and $R$ (Fig. 6b) were closely related to water temperature, but these measures were unrelated to PAR $(P>0.5$; data not shown). Metabolic scaling linked $R$ and temperature (Eq. $4 ; r^{2}=$ $0.73, n=6, P=0.031)$ with a slope of $-0.98 \pm 0.3 \mathrm{eV}$. The $z$ scores for $v_{\mathrm{f}}$ and temperature trended toward significance (Fig. 6c), while the $z$ scores for $U$ and temperature were highly correlated (Fig. 6d).

Across all streams and $\mathrm{N}$ release experiments, $v_{\mathrm{f}}$ and $U$ were closely related to $R$ as untransformed data $(r=$ 0.75 and 0.73 , respectively, $P<0.0001$; data not shown) or $z$ scores $(r=0.71, P=0.001$ and $r=0.50, P=0.004$, respectively; Appendix K). Similar global relationships were not significant for GPP and uptake. No metabolic or $\mathrm{N}$ uptake measures were significantly related to stream temperature across all releases using either untransformed data or associated $z$ scores. Accordingly, metabolic scaling revealed that respiration rates and temperature were unrelated $\left(r^{2}=0.05, n=22, P=0.29\right)$ when all streams and seasons were included. However, the relationship was significant $\left(r^{2}=0.46, n=18, P=\right.$ $0.002)$ with a slope $(-0.63 \pm 0.17 \mathrm{eV})$ remarkably similar to the predicted value (i.e., $-0.64 \mathrm{eV}$ ) when autumnal data from forested streams were excluded.

\section{Discussion}

Our assessment of $\mathrm{N}$ cycling in forested and opencanopied headwater streams showed that seasonal variation in $\mathrm{N}$ cycling within a stream can be as great as variance observed across very different systems within a single season (Appendix D). Nevertheless, metabolism and $\mathrm{N}$ uptake changed predictably with season within forested and open-canopied stream types, and temporal patterns appear to reflect the relative influences of resource subsidies and energetic constraints.

Endogenous control of ecosystem function.-While our data show that gross primary production (GPP) and respiration $(R)$ were closely linked to measures of $\mathrm{N}$ uptake in open-canopied and forested streams, respectively, $\mathrm{N}$ uptake and metabolic rates were also correlated with water temperature. While correlations were significant in both stream types, they were positive in open- 

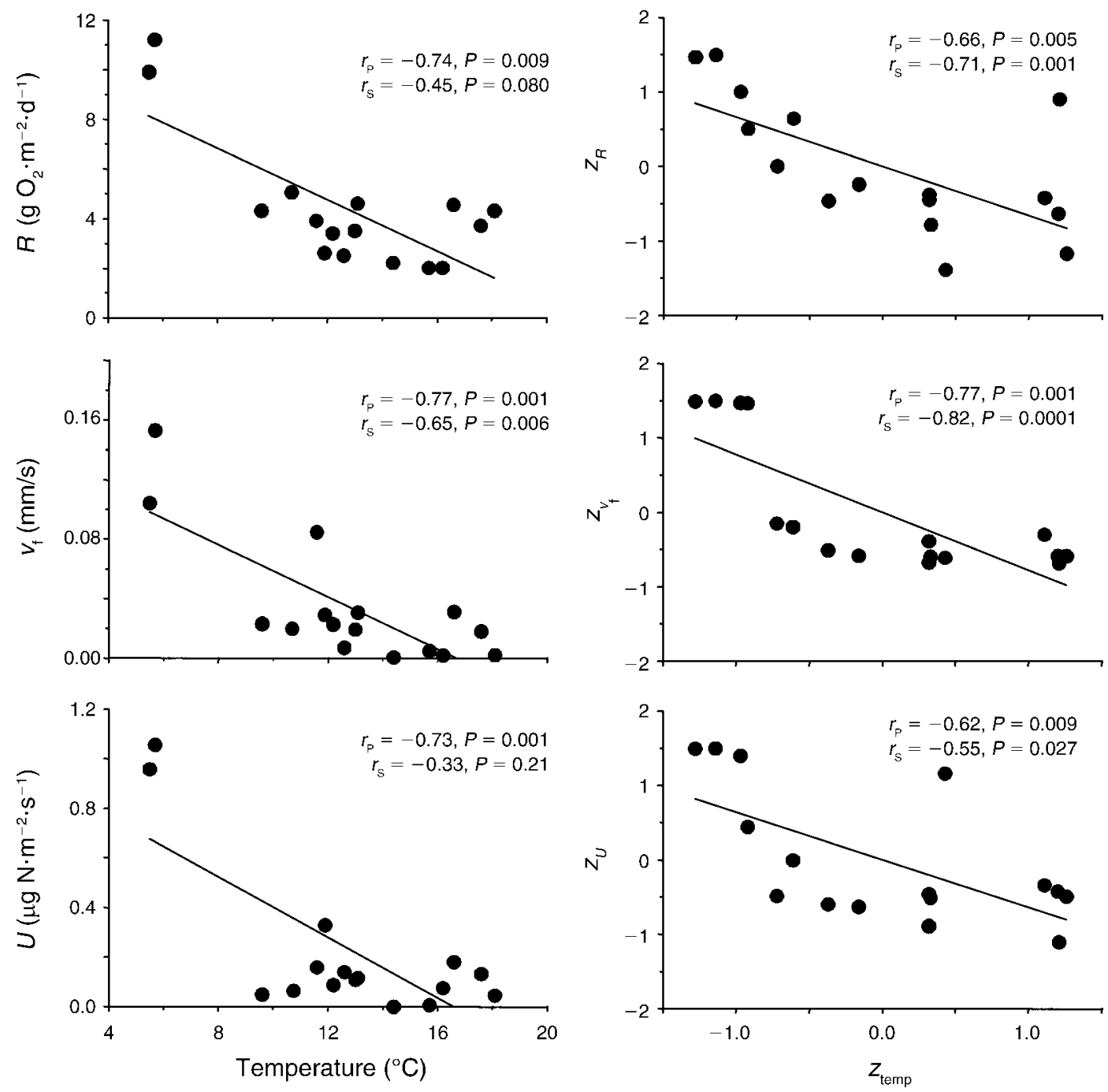

FIG. 4. Respiration $\left(R\right.$ and $\left.z_{\mathrm{R}}\right)$, uptake velocity $\left(v_{\mathrm{f}}\right.$ and $\left.z_{v_{\mathrm{f}}}\right)$, and areal uptake $\left(U\right.$ and $\left.z_{\mathrm{U}}\right)$ vs. temperature and its $z$ score in forested streams ( $n=16$ solute injections).

canopied systems and negative in forested streams. These data suggest that the relative influence of thermal energy may differ substantially among systems with differing timing and propensity for material exchange.

The argument that temperature should drive ecosystem metabolism (Enquist et al. 2003, Brown et al. 2004) seems appropriate for relatively closed systems. In these circumstances, productivity is maintained primarily by internal cycling, ecosystem function is heavily influenced by endogenous controls without punctuated external augmentation of energy flow, and light serves as the primary resource input. Such conditions characterize our more autochthonous-based open-canopied sites. Streams of this type displayed positive correlations between temperature, metabolism, and $\mathrm{N}$ uptake, suggesting a chain of causality from thermal energy to biological processes of metabolism and $\mathrm{N}$ uptake. This notion is supported by a significant relationship between metabolic rate and temperature across our opencanopied experiments, as predicted by the scaling rules of Enquist et al. (2003).

Others studies have shown that higher temperatures increase metabolic rates (Busch and Fisher 1981, Carpenter et al. 1992) and N cycling (Simon et al. 2005) in open-canopied streams and larger river systems (Uehlinger 2000). Further, thermal control has been recognized as an important endogenous driver for lakes via influences on metabolism and energy transfer through food webs (Carpenter et al. 1992, Winder and Schindler 2004). Endogenous thermal control is not limited to freshwater aquatic systems. In Tomales Bay, California, USA, as much as $90 \%$ of annual gross metabolism is supported by nutrient recycling, and ecosystem metabolic rates are positively correlated with water temperature (Smith and Hollibaugh 1997). Further, in the absence of limitation by water, many 

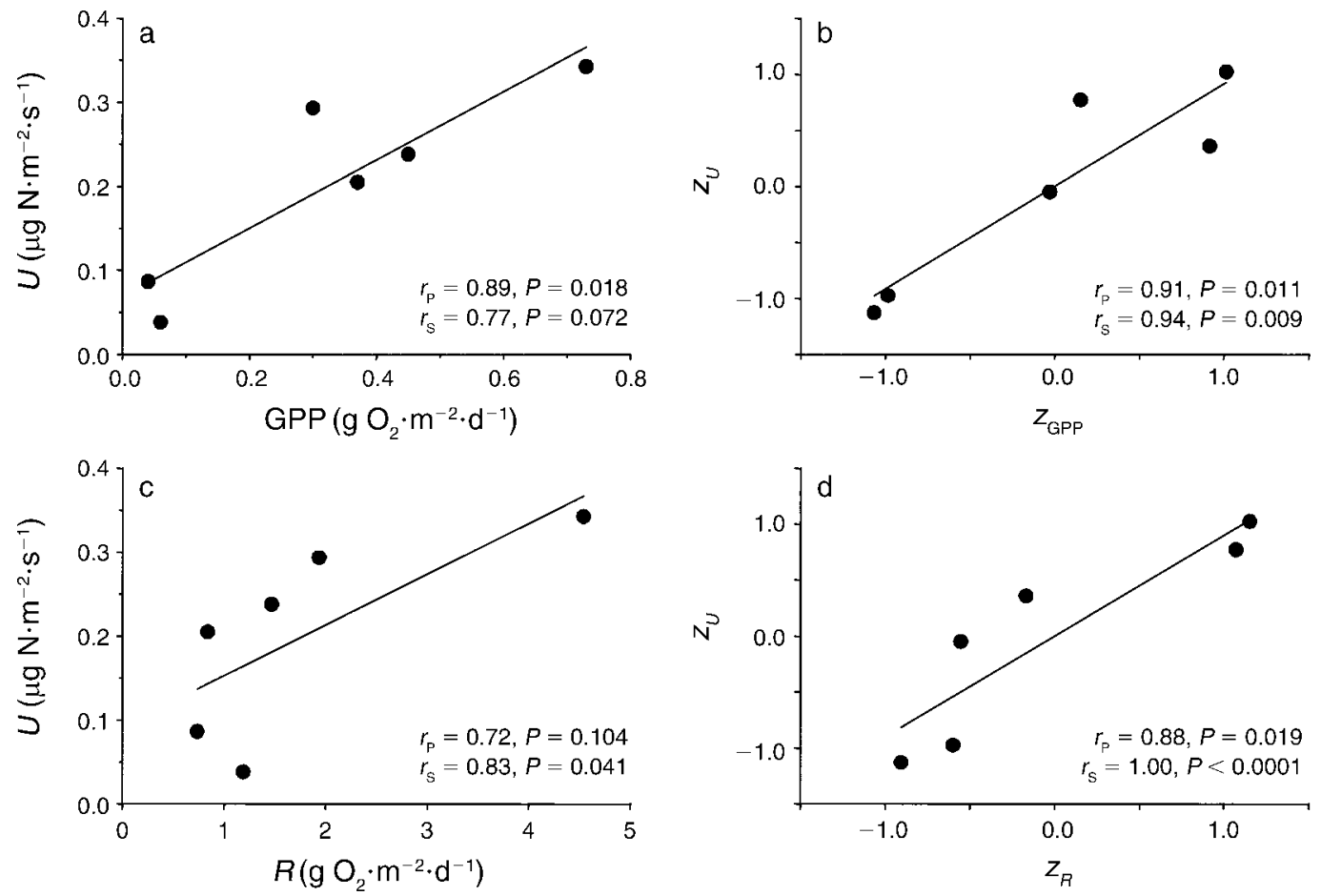

FIG. 5. The relationship between metabolism and $\mathrm{N}$ uptake during solute releases in open-canopied streams $(n=6$ solute injections). Areal uptake $(U)$ vs. gross primary production (GPP) and respiration $(R)$ for (a, c) untransformed data and (b, d) their $z$ scores.
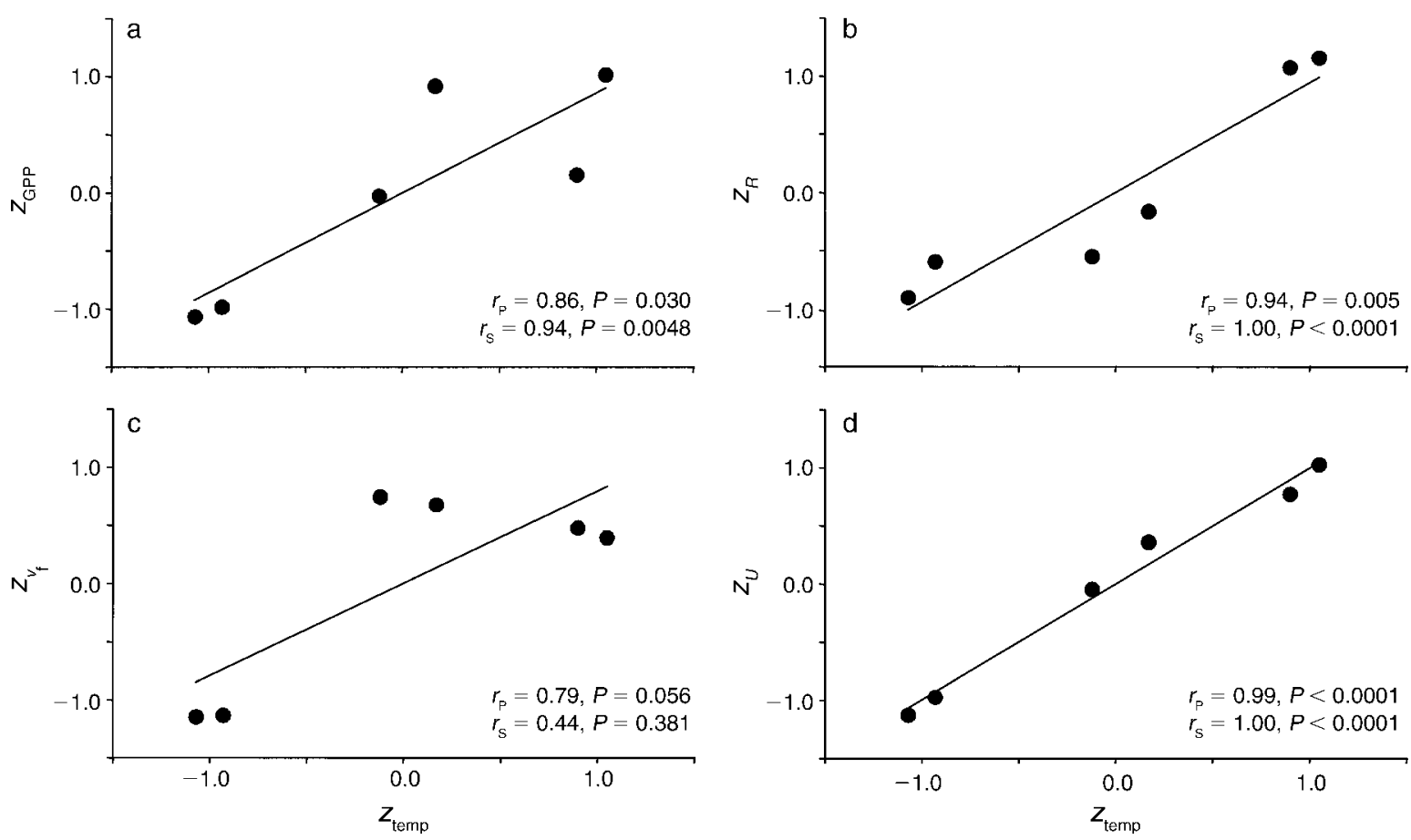

FIG. 6. The $z$ scores for (a, b) ecosystem metabolism and (c, d) N uptake vs. $z$ scores for temperature in open-canopied streams ( $n=6$ solute injections). Abbreviations: GPP, gross primary production; $R$, respiration; $U$, areal uptake; $v_{\mathrm{f}}$, uptake velocity. 


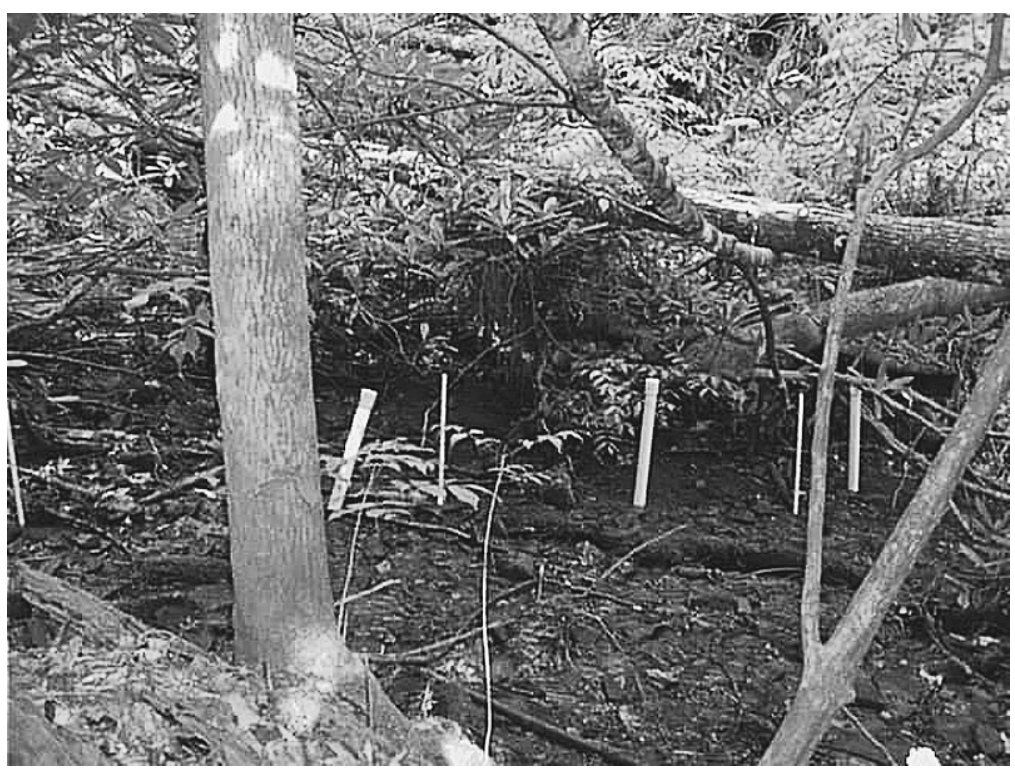

Plate 1. Photograph of a sampling station on Hugh White Creek, Coweeta Hydrologic Laboratory, North Carolina, USA. Note the dense rhododendron understory. Plentiful detrital material obscures the wetted channel. PVC wells and minipiezometers are evident and associated with other NPARS study objectives. Photo credit: H. M. Valett.

terrestrial systems may be viewed as endogenously controlled, with thermal energy dictating rates of metabolism and nutrient cycling (Davidson et al. 1998, 2006).

Exogenous control of ecosystem function.-Energetic and material subsidies can be important drivers of ecosystem structure and function in a host of settings (Polis et al. 2004). They may act as exogenous factors that alter the relative supply of $\mathrm{C}, \mathrm{N}$, or $\mathrm{P}$ and exert stoichiometric control (Sterner and Elser 2002) over rates of metabolism and nutrient cycling. Pulsed inputs (i.e., non-steady-state conditions) of resources may generate patterns of ecosystem function not predicted by thermal energy. In streams, subsidies of terrestrial litter have historically organized our thinking about metabolism and ecosystem function in general (e.g., Fisher and Likens 1973). Results from our study and earlier work have shown that leaf litter inputs increase $R$ and demand for $\mathrm{N}$ or $\mathrm{P}$. In part, these relationships reflect the recipient nature of streams and low nutrient quality of allochthonous organic matter. Dodds et al. (2004) showed that C:N ratios of living (e.g., epilithon) and nonliving (e.g., detritus) organic matter (OM) were strong predictors of $\mathrm{N}$ uptake in streams. They emphasized that high $\mathrm{C}: \mathrm{N}$ compartments in streams enhance $\mathrm{N}$ retention. While researchers have only recently begun to apply the perspectives of ecological stoichiometry to open ecosystems (Cross et al. 2005, Schade et al. 2005), it is logical that material import from adjacent ecosystems alters resource stoichiometry, with ramifications for rates of metabolism and $\mathrm{N}$ cycling.
Metabolic and $\mathrm{N}$ cycling rates in our forested streams were negatively correlated with temperature, suggesting an uncoupling of thermal control in the face of large resource subsidies. This contention is supported by our observation that excluding forested-stream autumnal respiration resulted in a strong fit (with the predicted slope) between metabolism and temperature following metabolic scaling laws, while their inclusion resulted in a slope not different from zero. Other ecosystems are subject to material subsidies with implications for energy flow and nutrient cycling. Hung and Huang (2005) emphasized that nutrient uptake in a tropical estuary was dictated by seasonal freshwater inputs of organic $\mathrm{C}$ and particulate-bound nutrients. Rivera-Monroy et al. (1998) illustrated a decoupling of temperature from metabolism and $\mathrm{N}$ uptake associated with forest $\mathrm{OM}$ inputs in a tropical mangrove swamp.

Alternation and integration of exogenous and endogenous control.-Greater temporal resolution of the importance of terrestrial subsidies and in-stream control of metabolism and nutrient dynamics may reveal lotic ecosystems characterized by periods of both exogenous and endogenous control. In earlier studies, we documented the importance of autotrophs for $\mathrm{N}$ uptake in forested streams, including the East and West Forks of Walker Branch (Mulholland et al. 2000, Fellows et al. 2006) and showed that daytime $\mathrm{N}$ uptake was greater than nighttime uptake during early spring periods of elevated insolation before full canopy development (Mulholland et al. 2006). Later in spring, when light levels were greatly reduced, $\mathrm{N}$ uptake rates were lower, and diurnal and nocturnal $\mathrm{N}$ uptake were no longer 
different. Moreover, Roberts et al. (2007) found that the spring pulse of primary production in West Fork Walker Branch supported rates of respiration similar to those observed during autumn when respiration was subsidized by terrestrial leaf litter. Net uptake of inorganic $\mathrm{N}$ was also considerably higher during the spring GPP pulse.

The influential role of terrestrial OM inputs was evident in forested streams, in part, because they occurred during colder weather and overwhelmed endogenous thermal control. Despite being well lit, our open-canopied streams were characterized by $P: R$ ratios substantially less than one, illustrating the importance of imported OM to ecosystem metabolism. Moreover, our earlier work at Rio Calaveras documented the importance of watershed delivery of nutrients to benthic algal communities (Peterson et al. 2001) and C for heterotrophic metabolism in the adjacent alluvial aquifer (Baker et al. 2000). Thus while these streams appear to be under thermal control, they are also influenced by inputs that occur under warmer conditions (i.e., late spring and early summer) when subsidies may act in concert with thermal trends to enhance rates of metabolism and material cycling during warmer periods.

A combination of exogenous and endogenous control may be typical of most ecosystems. A coastal inlet on the Iberian peninsula alternated between exogenous control via oceanic upwelling and endogenous periods when metabolic rates and nutrient sequestration were driven by temperature (Pérez et al. 2000). Similar patterns of intermittent alternation of control by oceanic upwelling have been documented for continental shelves off New Zealand (Zeldis 2004) and Massachusetts (Hopkinson et al. 2001). Gu et al. (2004) argued that imported labile OM decoupled soil $R$ from endogenous thermal control, emphasizing periods of exogenous influence in a system typically thought to be endogenously controlled. We suggest that for many ecosystems, endogenous control is the baseline and that episodic inputs of nutrients, organic matter, and other resources drive more open ecosystems away from endogenous control toward exogenous control for periods of time ranging from days (reflecting storms) to seasons (periods of higher connectivity) to even years (e.g., successional trajectories; Valett et al. 2002).

\section{ACKNOWLEDGMENTS}

The authors acknowledge the help of numerous individuals at the Biology Annex, UNM, and the VT Stream Team. This research is a product of the Nitrate Processing and Retention in Stream program and NSF grants DEB 98-15868 to H. M. Valett and J. R. Webster, DEB 98-16087 to C. N. Dahm, and DEB 98-16091 to C. G. Peterson.

\section{Literature Cited}

APHA (American Public Health Association, American Water Works Association, Water Environment Federation). 2006. Standard methods for examination of water and wastewater. Twenty-first edition. American Public Health Association, Washington, D.C., USA.
Baker, M. A., H. M. Valett, and C. N. Dahm. 2000. Organic carbon retention and metabolism in a near-stream groundwater ecosystem. Ecology 81:3133-3148.

Brown, J. H., J. F. Gillooly, A. P. Allen, V. M. Savage, and G. B. West. 2004. Toward a metabolic theory of ecology. Ecology 85:1771-1789.

Busch, D. E., and S. G. Fisher. 1981. Metabolism of a desert stream. Freshwater Biology 11:301-308.

Carpenter, S. R., S. G. Fisher, N. B. Grimm, and J. F. Kitchell. 1992. Global change and freshwater ecosystems. Annual Review of Ecology and Systematics 23:119-139.

Cole, J. J., S. R. Carpenter, M. L. Pace, M. C. Van de Bogert, J. L. Kitchell, and J. R. Hodgson. 2006. Differential support of lake food webs by three types of terrestrial organic carbon. Ecology Letters 9:558-568.

Cross, W. F., J. P. Benstead, P. C. Frost, and S. A. Thomas. 2005. Ecological stoichiometry in freshwater benthic systems: recent progress and perspectives. Freshwater Biology 50: 1895-1912.

Davidson, E., E. Belk, and R. D. Boone. 1998. Soil water content and temperature as independent or confounded factors controlling soil respiration in a temperate mixed hardwood forest. Global Change Biology 4:217-227.

Davidson, E., I. A. Janssens, and Y. Luo. 2006. On the variability of respiration in terrestrial ecosystems: moving beyond the $\mathrm{Q}_{10}$. Global Change Biology 12:154-164.

DeAngelis, D. L., and P. J. Mulholland. 2004. Dynamic consequences of allochthonous input to freshwater systems. Pages 12-24 in G. A. Polis, M. E. Power, and G. R. Huxel, editors. Food webs at the landscape scale. University of Chicago Press, Chicago, Illinois, USA.

Dodds, W. K., E. Martí, J. L. Tank, J. Pontius, S. K. Hamilton, N. B. Grimm, W. B. Bowden, W. H. McDowell, B. J. Peterson, H. M. Valett, J. R. Webster, and S. V. Gregory. 2004. Carbon and nitrogen stoichiometry and nitrogen cycling rates. Oecologia 140:458-467.

Enquist, B. J., J. H. Brown, and G. B. West. 1998. Allometric scaling of plant energetics and population density. Nature 395:163-165.

Enquist, B. J., E. P. Economo, T. E. Huxman, A. P. Allen, D. D. Ignace, and J. F. Gillooly. 2003. Scaling metabolism from organisms to ecosystems. Nature 423:639-642.

Fellows, C. S., H. M. Valett, C. N. Dahm, P. J. Mulholland, and S. A. Thomas. 2006. Nutrient uptake and energy flow: coupling ecosystem function in headwater streams. Ecosystems 9:788-804.

Fisher, S. G., and G. E. Likens. 1973. Energy flow in Bear Brook, New Hampshire: an integrative approach to stream ecosystem metabolism. Ecological Monographs 43:421-439.

Gillooly, J. F., J. H. Brown, G. B. West, V. M. Savage, and E. L. Charnov. 2001. Effects of size and temperature on metabolic rate. Science 293:2248-2251.

Gordon, N. D., T. A. McMahon, and B. L. Finlayson. 1992. Stream hydrology: an introduction for ecologists. John Wiley and Sons, New York, New York, USA.

Gu, L. H., W. M. Post, and A. W. King. 2004. Fast labile carbon turnover obscures sensitivity of heterotrophic respiration from soil to temperature: a model analysis. Global Biogeochemical Cycles 18:GB1022.

Hanski, I. 1998. Connecting the parameters of local extinction and metapopulation dynamics. Oikos 83:390-396.

Helfield, J. M., and R. J. Naiman. 2006. Keystone interactions: salmon and bear in riparian forests of Alaska. Ecosystems 9: $167-180$

Hopkinson, C. S., A. E. Giblin, and J. Tucker. 2001. Benthic metabolism and nutrient regeneration on the continental shelf of eastern Massachusetts, USA. Marine Ecology Progress Series 224:1-19.

Hung, J.-J., and M.-H. Huang. 2005. Seasonal variations in organic-carbon and nutrient transport through a tropical 
estuary (Tsengwen) in southwestern Taiwan. Environmental Geochemistry and Health 27:75-95.

Maron, J. L., J. A. Estes, D. A. Croll, E. M. Danner, S. C. Elmendorf, and S. L. Buckelew. 2006. An introduced predator alters Aleutian Island plant communities by thwarting nutrient subsidies. Ecological Monographs 76:324.

Marzolf, E. R., P. J. Mulholland, and A. D. Steinman. 1994. Improvements to the diurnal upstream-downstream dissolved oxygen change technique for determining wholestream metabolism in small streams. Canadian Journal of Fisheries and Aquatic Sciences 51:1591-1599.

Mulholland, P. J., J. L. Tank, D. M. Sanzone, W. M. Wollheim, B. J. Peterson, J. R. Webster, and J. L. Meyer. 2000 . Nitrogen cycling in a forest stream determined by a ${ }^{15} \mathrm{~N}$ tracer addition. Ecological Monographs 70:471-493.

Mulholland, P. J., S. A. Thomas, H. M. Valett, J. R. Webster, and J. Beaulieu. 2006. Effects of light on nitrate uptake in small forested streams: diurnal and daily variations. Journal of the North American Benthological Society 24:753-768.

Nagasaka, A., Y. Nagasaka, K. Ito, T. Mano, M. Yamanaka, A. Katayama, Y. Sato, A. L. Grankin, A. I. Zdorikov, and G. A. Boronov. 2006. Contributions of salmon-derived nitrogen to riparian vegetation in the northwest Pacific region. Journal of Forest Research 11:377-382.

Newbold, J. D., J. W. Elwood, R. V. O'Neill, and W. Van Winkle. 1981. Measuring nutrient spiraling in streams. Canadian Journal of Fisheries and Aquatic Sciences 38: 860-863.

Odum, E. P., and A. A. de la Cruz. 1963. Detritus as a major component of ecosystems. AIBS Bulletin 13:39-40.

Odum, H. T. 1956. Primary production in flowing waters. Limnology and Oceanography 1:102-117.

Pace, M. L., J. J. Cole, S. R. Carpenter, and J. F. Kitchell. 1999. Trophic cascades revealed in diverse ecosystems. Trends in Ecology and Evolution 14:483-488.

Pérez, F. F., X. A. Álvarez-Salgado, and G. Róson. 2000. Stoichiometry of the net ecosystem metabolism in a coastal inlet affected by upwelling. The Ría de Arousa (NW Spain). Marine Chemistry 69:217-236.

Peterson, B. J., R. W. Howarth, and R. H. Garritt. 1986. Sulfur and carbon isotopes as tracers of salt-marsh organic matter flow. Ecology 67:865-874.

Peterson, C. G., H. M. Valett, and C. N. Dahm. 2001. Shifts in habitat templates for lotic microalgae linked to interannual variation in snowmelt intensity. Limnology and Oceanography $46: 858-870$.

Polis, G. A., M. E. Power, and G. R. Huxel, editors. 2004. Food webs at the landscape scale. University of Chicago Press, Chicago, Illinois, USA.

Pulliam, H. R. 1988. Sources, sinks, and population regulation. American Naturalist 132:652-661.

Rivera-Monroy, V. H., C. J. Madden, J. W. Day, Jr., R. R. Twilley, F. Vera-Herrera, and H. Alvarez-Guillen. 1998. Seasonal coupling of tropical mangrove forest and an estuarine water column: enhancement of aquatic primary productivity. Hydrobiologia 379:41-53.

Roberts, B. J., P. J. Mulholland, and W. R. Hill. 2007. Multiple scales of temporal variability in ecosystem metabolism rates: results from 2 years of continuous monitoring in a forested headwater stream. Ecosystems 10:588-606.

Schade, J. D., J. F. Espeleta, C. A. Klausmeier, M. E. McGroddy, S. A. Thomas, and L. X. Zhang. 2005. A conceptual framework for ecosystem stoichiometry: balancing resource supply and demand. Oikos 109:40-51.

Sigman, D. M., M. A. Altabet, R. Michener, D. C. McCorkle, B. Fry, and R. M. Holmes. 1997. Natural abundance-level measurement of nitrogen isotopic composition of oceanic nitrate: an adaptation of the ammonium diffusion method. Marine Chemistry 57:227-242.

Simon, K. S., C. R. Townsend, B. J. F. Biggs, and W. B. Bowden. 2005. Temporal variation in $\mathrm{N}$ and $\mathrm{P}$ uptake in 2 New Zealand streams. Journal of the North American Benthological Society 24:1-18.

Smith, S. V., and J. T. Hollibaugh. 1997. Annual cycle and interannual variability of ecosystem metabolism in a temperate climate embayment. Ecological Monographs 67:509-533.

Sokal, R. R., and F. J. Rohlf. 1981. Biometry. Second edition. W. H. Freeman, New York, New York, USA.

Steinman, A. D., G. A. Lamberti, and P. R. Leavitt. 2006. Biomass and pigments of benthic algae. Pages 357-380 in F. R. Hauer and G. A. Lamberti, editors. Methods in stream ecology. Academic Press, New York, New York, USA.

Sterner, R. W., and J. J. Elser. 2002. Ecological stoichiometry: the biology of elements from molecules to the biosphere. Princeton University Press, Princeton, New Jersey, USA.

Stream Solute Workshop. 1990. Concepts and methods for assessing solute dynamics in stream ecosystems. Journal of the North American Benthological Society 9:95-119.

Thomas, S. A., H. M. Valett, P. J. Mulholland, J. R. Webster, C. N. Dahm, and C. G. Peterson. 2001. Nitrogen retention in headwater streams: the influence of groundwater-surface water exchange. Scientific World 1:623-631.

Uehlinger, U. 2000. Resistance and resilience of ecosystem metabolism in a flood-prone river system. Freshwater Biology 45:319-332.

Valett, H. M., C. L. Crenshaw, and P. F. Wagner. 2002. Stream nutrient uptake, forest succession and biogeochemical theory. Ecology 83:2888-2901.

Webster, J. R., et al. 2003. Factors affecting ammonium uptake in streams: an inter-biome perspective. Freshwater Biology 48:1329-1352.

Webster, J. R., S. W. Golladay, E. F. Benfield, J. L. Meyer, W. T. Swank, and J. B. Wallace. 1992. Catchment disturbance and stream response: an overview of stream research at Coweeta Hydrologic Laboratory. Pages 232-252 in P. J. Boon, P. Calow, and G. E. Petts, editors. River conservation and management. John Wiley and Sons, Chichester, UK.

Webster, J. R., and B. C. Patten. 1979. Effects of watershed perturbation on stream potassium and calcium dynamics. Ecological Monographs 49:51-72.

Winder, M., and D. E. Schindler. 2004. Climate uncouples trophic interactions in an aquatic ecosystem. Ecology 85: 2100-2106.

Zeldis, J. R. 2004. New and remineralized nutrient supply and ecosystem metabolism on the northeastern New Zealand continental shelf. Continental Shelf Research 24:563-581.

\section{APPENDIX A}

Study sites and stream characteristics during seasonal ${ }^{15} \mathrm{NO}_{3}^{-}$addition experiments (Ecological Archives E089-200-A1).

\section{APPENDIX B}

Average stream characteristics across all injections for each of the three study sites (Ecological Archives E089-200-A2). 


\section{APPENDIX C}

Principal components analysis (PCA) of seasonal samples in structural space (Ecological Archives E089-200-A3).

\section{APPENDIX D}

Spatial and temporal variation in spiraling metrics among sites and seasons (Ecological Archives E089-200-A4).

\section{APPENDIX E}

Average epilithic standing crops from all injections for each of the three study sites (Ecological Archives E089-200-A5).

\section{APPENDIX F}

Seasonal means of physical and chemical features of study streams in forested and open-canopy conditions (Ecological Archives E089-200-A6).

\section{APPENDIX G}

Seasonal organic matter standing stocks for benthic and hyporheic fine particulate organic matter, coarse particulate organic matter, and wood in forest streams (Ecological Archives E089-200-A7).

\section{APPENDIX H}

Organic matter standing crops for autochthonous primary uptake compartments in forested and open-canopied streams (Ecological Archives E089-200-A8).

\section{APPENDIX I}

Seasonal metabolic measures for forested and open-canopied streams (Ecological Archives E089-200-A9).

\section{APPENDIX J}

Seasonal spiraling metrics for forested and open-canopied streams (Ecological Archives E089-200-A10).

\section{APPENDIX K}

The $z$ scores for uptake velocity and areal uptake vs. $z$ scores for respiration across all sites and seasons (Ecological Archives E089-200-A11). 